Magyar Honvédség Egészségügyi Központ Honvédkórház, a SE-ÁOK Oktató Kórháza Szemészeti Osztály

\title{
Csak egy szürkehályog? Cataracta mütétek extrém helyzetekben
}

\author{
Dr. Vogt Gábor orvos ezredes, PhD
}

Kulcsszavak: szürkehályog mütét, különleges esetek, szemsérülés, luxált lencse, szük pupilla, floppy írisz

\begin{abstract}
A szerző áttekinti a szürkehályog sebészet elmúlt évtizedeinek fejlődését, a mütéti eszközök, módszerek és a mütéti indikáció változását. A szürkehályog mütét a legsikeresebb és leggyakoribb emberen végzett „rutin” mütéti beavatkozás a világon, ugyanakkor a különleges esetek megoldása különös figyelmet és kreativitást igényel a szemsebészektöl, ezekröl szól ez a közlemény.
\end{abstract}

A szemlencse elhomályosodását szürkehályognak nevezzük. Ez az utóbbi időben egyre fiatalabb életkorban elöforduló betegség a látás fokozatos, fájdalom nélküli romlásával jár, ami szemüveggel nem javítható, hiszen az elszürkülő lencse gátolja a fénysugarak bejutását a szembe. Az erősödő UV-sugárzásnak és egyes általános és szembetegségek gyakoribb elöfordulásának szerepe van abban, hogy a cataracta egyre fiatalabb életkorban jelentkezik. Korunk fokozott látásigénye (számítógép-használat, gépkocsivezetés) miatt sokszor már a kezdődő hályog is olyan zavaró, hogy lehetetlenné teszi a beteg mindennapi tevékenységének, munkájának elvégzését. A szürkehályog-képződést gyógyszeres kezeléssel, diétával visszafordítani nem lehet, mütéttel azonban jól gyógyítható.

Évtizedekkel ezelőtt a betegeknek meg kellett várniuk, amíg szürkehályogjuk teljesen megérik, mert a mütétet csak ezután lehetett az akkori módszerekkel biztonságosan elvégezni. Az operáció során a szemen nagyméretü sebet készítettek (1. ábra), amelyen keresztül a szemlencsét eltávolították. A sebet varratokkal zárták, majd a beteg vastag „szódásüveg” szemüveget kapott, hiszen az eltávolított szemlencse optikai hatását ekkor még nem tudták beültethető müanyag lencsével helyettesíteni. A betegek gyógyulása hosszú hónapokig tartott, a szem fénytörése (a nagyméretü seb hegesedése, a varratok húzó hatása miatt) folyamatosan változott, így a végleges szemüveg felírására fél-egy évet kellett várniuk.

Mára, a mütéti eljárások fejlődésének köszönhetően, a helyzet alapvetően megváltozott. Nem kell, sőt nem is szabad megvárni, hogy a szürkehályog megérjen, a látás teljesen elromoljon, mert 


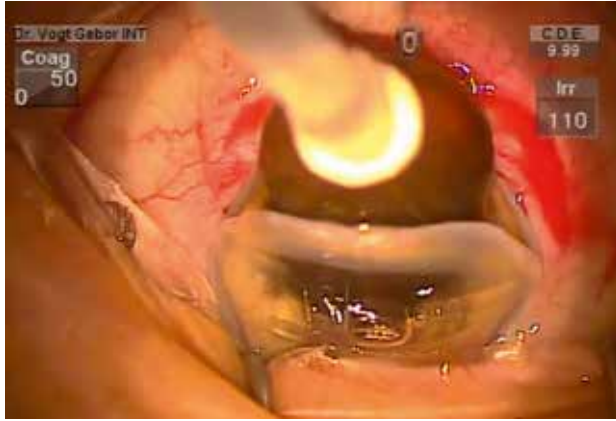

1. ábra. Szemlencse eltávolitása egészben, nagyméretü seben

keresztül, ahogy évtizedekkel ezelött, a fakoemulzifikáció elötti időben történt.

akkor a számos előnnyel járó korszerü műtéti technika, a fakoemulzifikáció nehezebben végezhető el. A számos nehezítő tényező közül az első, hogy érett hályog esetében nincs vörös visszfény, ezért a lencse első tokjának szabályos kerek meghasítása, a capsulorhexis csak akkor végezhető el, ha a tokot megfestjük, különben a hasítás nem látható. A másik, hogy a szemlencse beltartamának volumene megnő, duzzad és ezért az elülső tok megnyitásakor hirtelen szétszakadhat a tok, ami lehetetlenné teheti a szabályos capsulorhexis elvégését. A harmadik, az hogy a lencse magja megkeményedik, ami megnehezíti a szemen belüli szétdarabolását. A negyedik pedig, hogy a lencse hátsó tokján makacs felrakódások alakulhatnak ki. Ötödikként pedig a lencsetartó szalagok, a zonulák meggyengülését kell említeni, ami a lencse elmozdulásához vezethet. Mindezek miatt a mütét érett hályog esetén sokkal kockázatosabb, több komplikáció veszélyét rejti és jelentősen hoszszabb lesz mind maga a mütét, majd a gyógyulás is.

A legkorszerübb szürkehályogmütét során - amit a MH EK Honvédkórház Szemészeti osztályán végzünk - egy speciális készülék, a fakoemulzifikátor segítségével az elhomályosodott lencsét ultrahang-energia felhasználásával a szemen belül feldaraboljuk, majd a szemből kiszívjuk úgy, hogy mindössze egy 2 milliméteres sebet készítünk. Az eltávolított lencse optikai hatását mülencsével pótoljuk, amit az eredeti szemlencse kitisztított tokjába ültetünk be. A 6,0 milliméter optikai átmérőjű műanyag lencse csak akkor fér be a kis méretü seben keresztül a szembe, ha speciális lágy anyagból készül, ezért összehajtható. Injektor segítségével implantáljuk a szembe, ahol azután ismét felveszi eredeti alakját. Ezzel a technikával elkerülhetjük a seb megnagyobbítását. A seb kis mérete és speciális alakja lehetővé teszi, hogy a metszés varratok behelyezése nélkül záródjon.

Ez a mütéti módszer a hagyományos szürkehályog-operációnál sokkal bonyolultabb, az orvostól kimagasló tudást követel. A mindennapi gyakorlatban azonban rendkívüli előnyöket jelent a beteg számára: a mülencse beültetésével feleslegessé válik a vastag szemüveg viselése, hamar javul a látás, nincs varrat okozta irritáció és sebtorzító hatás.

Gyakran felvetődik a kérdés hogy ez lézeres szürkehályog mütét-e? A válasz előtt néhány gondolatot engedjenek meg a modern szürkehályog operáció történetével kapcsolatban. Hazánkban az első lézeres szürkehályog mütétet mi végeztük, az első közleményt ezzel kapcsolatban mi közöltük [1], hasonlóan nevünkhöz füződik az ultrahangos szürkehályog (phacoemulsifikáció) mütétre való áttérés első leírása [2], valamint az első hajlékony mülencsékkel foglalkozó tudományos konferencia [3] megszervezése. Mire képes a lézer? A lézerrel vágni, vagy koagulálni lehet a szöveteket akár a szemen belül is. Mire nem képes a lézer? Nem képes az elszürkült 


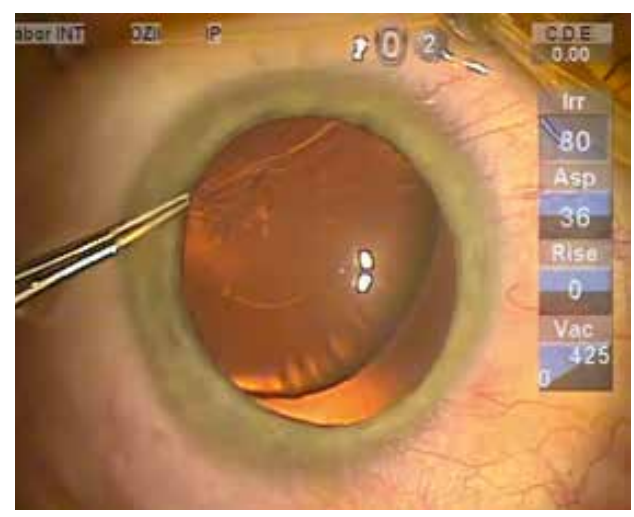

2/a ábra. Sérülés után elmozdult szemlencse esetében végzett tokhasitás $2 m m$-es seben keresztül. A lencse tartó szalagok - a zonulák - 2-töl 8 óráig leszakadtak

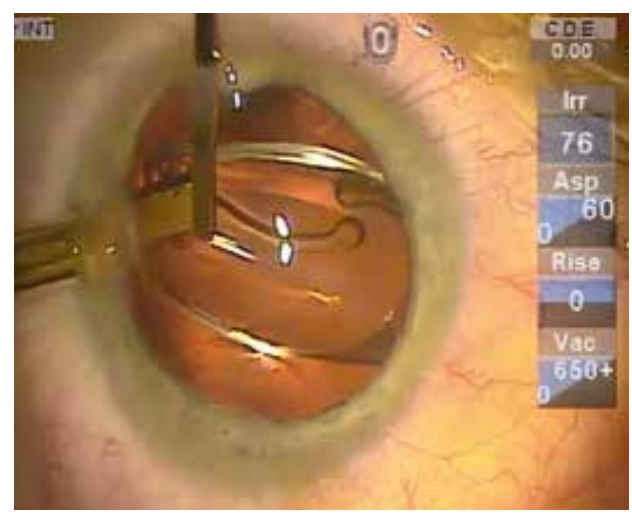

2/c ábra. A tokfeszitö gyürü beültetése után a lencsetok a helyére került, a lencse magját fakoemulzifikátorral eltávolitottuk, a kérget iirigatio/asprációval leszívtuk, a képen az látható amint a mülencsét injectorral a tokba ültetjük.

szemlencsét eltávolítani a szemből és nem képes a helyére mülencsét beültetni. Akkor mire jó a lézer a szürkehályog sebészetben? Nagyon jó arra, amire mindennap használjuk: az utóhályog gyógyítására, ami nem más, mint a mülencse beültetése után hosszabb - rövidebb idővel kialakuló homály a mülencsét tartó eredeti szemlencse tokján,

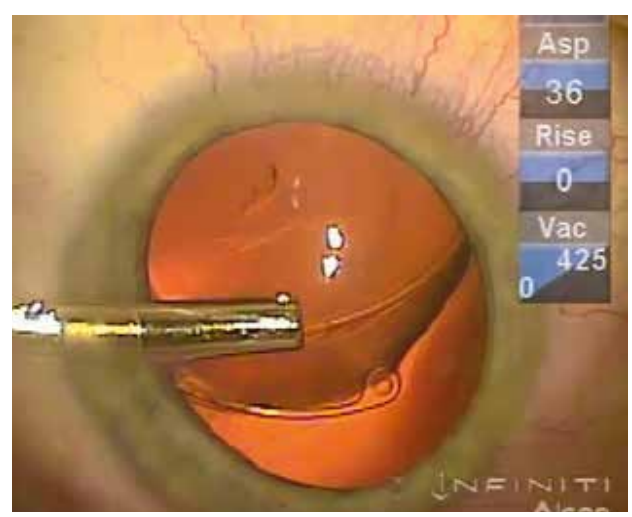

2/b ábra. Tokfeszitö gyürübehelyezése injektorral.

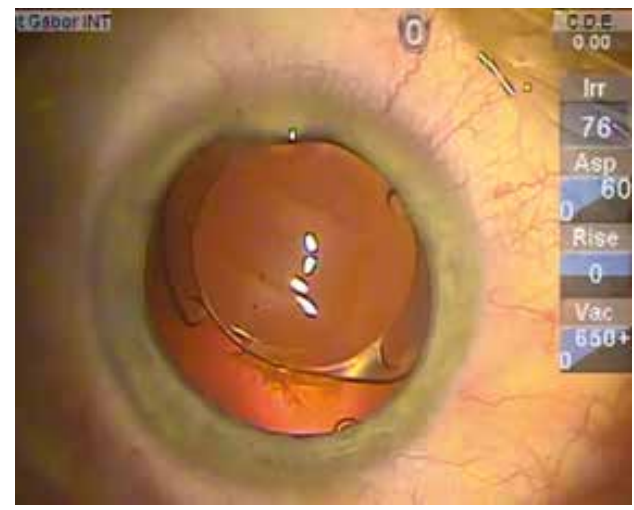

2/d ábra. A mülencse fokozatosan szétnyílik a tokban, a tokfeszitö gyürü hatására az elmozdult lencsetok centrálissá vált.

amit Nd-YAG lézerrel lehet el távolítani. Mire lehet még jó a lézer a szürkehályog operáció során? A műtét egyes lépései a hagyományos manuális technika helyett elvégezhetők egy speciális lézerrel, a femtolézerrel: elkészíthető vele a szaruhártya seb, a tokhasítás és alkalmas a lencsemagjának fellazítása, darabolása. A mütéthez azonban ugyanúgy szüksé- 
ges fakoemulzifikátor (az elszürkült lencse eltávolításához) és lézerrel értelemszerüen a mülencse sem ültethető be, vagyis csak a mütét egy kis részét tudjuk femtolézerrel kivitelezni. Használható másra is lézer? A szemészetben nagyon sokféle lézer kitűnően felhasználható különböző szembetegségek például zöldhályog, cukorbetegség szemészeti szövődményei, retina szakadások, koraszülöttek szemfenéki elváltozásainak kezelésében, illetve a szaruhártyán végzett refraktív beavatkozások esetében, utóbbiak célja a szemüveg elhagyása.

A korszerű szürkehályog mütét kapcsán fontos szempont a mülencse kiválasztása. A beültetendő egyfókuszú mülencse dioptriáját a beteggel való előzetes egyeztetés után úgy határozzuk meg, hogy vagy távolra, közelre vagy esetleg köztes távolságra biztosítson szemüveg nélkül éleslátást. Ilyenkor a mütét után egy távolságra lehet éles a látás, az egyéb távolságokra szemüveg viselésére lesz szükség. Külön térítés ellenében, amennyiben a szem erre alkalmas, léteznek olyan műlencsék is, amelyek távoli és közeli éleslátást is biztosítanak. A tórikus mülencsékkel, pedig a beteg mütét előtt meglévő asztigmatizmusát is javítani tudjuk. Vagyis ha beteg szürkehályogossá vált szemlencséjét műanyag lencsére cseréljük ki, megszüntethetjük a szem eredeti dioptria hibáját, és így a beteg adott esetben jobban láthat, mint korábban bármikor életében. Fontos azonban tudni, hogy ha a szürkehályogon kívül más szembetegsége is fennáll, például, zöldhályog, időskori szemfenéki elváltozás, cukorbetegség okozta retinopathia, akkor a látás a mütét után csak annyit javulhat, amenynyit a szürkehályog rontott rajta.

$\mathrm{Az}$ osztályunkon végzett mütétek rendkívül biztonságosak, a szövődmé- nyek száma elenyészően kicsi. A legmegbízhatóbb, legmodernebb műszereket alkalmazzuk, mütéti technikánkat folyamatosan fejlesztjük. Az operációhoz jól együttműködő beteg esetében nincs szükség altatásra és injekció adására sem. Csepp-érzéstelenítéssel tökéletesen elérzéstelenítjük a szemet, így a beteg nem érez fájdalmat sem a mütét alatt, sem utána. A sebgyógyulás gyors, a betegek hamar visszanyerik látásukat és rövidesen folytathatják korábbi tevékenységüket. Az operáció után rövid ideig idegentest-érzés, enyhe szúrás, könnyezés előfordul, a betegek egy része úgy érzi, mintha szempilla esett volna a szemébe. Nagyon fontos, hogy ezt ne próbálják eltávolítani, hiszen ezt az enyhe kellemetlenséget a gyógyuló néhány milliméteres seb okozza.

Melyek azok a helyzetek, amelyek megnehezítik a szürkehályog mütét elvégzését? Minden, ami eltér a megszokottól. Például ha a pupilla nem tágítható ki a mütéthez, ha tokhasítás elvégzéséhez nincs vörös visszfény, ha kemény a lencse magja, ha társuló általános és szembetegségek állnak fenn. A Hon- és Rendvédelmi Egészségügyi dolgozók VI. Tudományos Szakmai konferenciáján 2016 november 23-24-án erről tartottunk 20 speciális eset mütéti videó vetítésével illusztrált előadást „Csak egy szürkehályog? Cataracta mütétek extrém helyzetekben" címmel [4].

Osztályunk jellegéből adódóan az extrém helyzetek közül kiemelt helyen áll a sérült szemek ellátása. A cataracta traumatica kialakulhat áthatoló szemsérülés következtében, amikor a szemlencse direkt károsodhat, tokja megszakadhat, azonnal elszürkülhet, de akár kirepülhet a szemből, vagy elsülylyedhet az üvegtestben, vagy "csak” szubluxálódhat. Tompa szemsérülés kö- 
vetkeztében is elmozdulhat a lencse a helyéről, elszürkülhet azonnal, vagy akár hosszú évekkel a trauma után.

A lencsék nemcsak trauma, hanem bizonyos kötőszöveti rendszerbetegségek (pl. Marfan szindróma), vagy egy gyakori szemészeti eltérés a sokszor zöldhályoggal járó pseudoexfoliációs szindróma esetében is elmozdulhatnak a helyükről a zonulák (lencsetartó szalagok) gyengesége miatt. Érett és túlérett hályogok is zonula gyengeséggel járhatnak, a tokhasítás (capsulorhexis) nehézségeit fent részleteztük, említettük, hogy milyen fontos az első tok megfestése a megfelelő tokhasítás elvégzéséhez. A szürkehályog megérése esetén jelentkező egyéb nehézségeket is korábban részleteztük. A helyéről elmozdult lencséket a mütét során stabilizálni kell, amelyre a különböző tokstabilizáló gyürük, hurkok állnak rendelkezésünkre (2/a-d.ábra).

A szűk, szemcseppekkel nem tágítható pupilla segédeszközök alkalmazása nélkül lehetetlenné teszi a capsulorhexis elvégzését. Ilyenkor is számos lehetöség közül választhatunk: mechanikusan „push and pull” eszközzel megtágíthatjuk a pupillát, speciális viszkoelasztikus anyagokat alkalmazhatunk, tágíthatunk íriszhorgokkal, vagy Malyugin gyürüvel. Szűk pupillát okozhat pl. szivárványhártya gyulladás, glaukómás cseppek (pilocarpin) tartós használata, korábbi szemmütét.

A floppy írisz szindróma az utóbbi időben egyre gyakrabban nehezíti meg a mütétet. Ennek lényege az, hogy alfa receptor antagonista készítmények használata esetén a cataracta mütét során szivárványhártya rongyszerüen lebeg ezáltal lehetetlenné teszi a műtét atraumatikus elvégzését és súlyos komplikációk léphetnek fel. Leggyakrabban használt ilyen készítmény a tamsulosin, amit a szürkehályogos korú férfiak prosztata hiperplázia miatt gyakran szednek. Ide tartoznak azonban az egyéb alfa-1-receptor antagonisták a Doxazosin (Cardura, Doxagal, Doxazosin, Dixicard, Doxone), a Prazosin (Minipress), a Terazosin (Hytrin, Setegis), az Alfuzosin (Alfetim, Alfugen, Alfuzosin, Fetamozin). Floppy írisz szindrómát okoz még a Serenoa repens (Prostamol uno, Sabal Serrulata, Strogen uno - gyógynövénykivonat), a Mianserin (Tolvon, Miagen - alfa2 adrenerg antagonista, antidepresszív gyógyszer) és a Ropinirole (Requip dopamin agonista, Parkinzon ellenes gyógyszer). A gyógyszerek széles skálájából következik, hogy számos társszakmákban dolgozó kollegának lehet fontos szerepe egy súlyos műtéti szövődmény - a floppy írisz szindróma - megelőzésében.

Extrém helyzeteket jelenthet még a különböző szemészeti műtétek kombinációja például a zöld és szürkehályog műtét kombinációja, az üvegtest sebészeti beavatkozás (vitrectomia), vagy a szaruhártya mütét egyidejü végzése.

\section{Irodalom}

[1] Vogt G: Szürkehályog mütét laserrel vagy ultrahanggal? Szemészet, 2000, 137: 99-102.

[2] Vogt G, Czvikovszky Gy, Hatvani I, Ungváry $\mathrm{L}$ : Áttérés fakoemulzifikációra: két különböző műtéti technika összehasonlítása az első 50 eset tapasztalatai alapján. Szemészet, 1996, 133: 131.

[3] Hajlékony műlencsék hazánkban, Tudományos Országos Kongresszus, MÁV Kórház és Központi Rendelőintézet, Budapest, 1999. augusztus 28 . 
[4] Vogt G: Csak egy szürkehályog? Cataracta mütétek extrém helyzetekben Hon- és Rendvédelmi Egészségügyi dolgozók VI. Tudományos Szakmai konferenciája, Budapest, 2016. november 23-24.

\section{Col. G. Vogt MDMC, PhD}

Is it just a cataract surgery? Cataract surgery in challenging cases

The author surveys the development of cataract surgery in the last decades including the instrumentation, the tech- niques and the indication. The cataract surgery becomes the most frequent and successful human surgery in the world, but the solution of some challenging cases requires special attention and creativity for the eye surgeons. The topics of this article are these special cases.

Key-words: cataract surgery, challenging cases, eye trauma, lens luxation, small pupil, floppy iris

Dr. Vogt Gábor o. ezds., PhD 1062 Budapest, Podmaniczky u. 111. 